\title{
Giovanna Tomassucci*
}

iD https://orcid.org/0000-0001-5296-028X

\section{From Warsaw to Warsaw. Some remarks on the two 'imaginary translations' from Polish (1944) by Franco Fortini}

\section{'...anonymous as if they were translated from Polish, these two poems of mine'}

In contemporary Poland (as in the majority of former Soviet bloc countries) the name of Franco Fortini is virtually unknown, not only due to insufficient command of Italian among Polish scholars, but above all due to a shared mistrust towards someone who experienced a Marxist militancy in his biography. ${ }^{1}$ It is a pure paradox that the author of Foglio di via (Marching orders) was the only Italian poet

* Professor, Department of Filologia, Letteratura e Linguistica of the University of Pisa, giovanna.tomassucci@unipi.it.

1 This article has been published in Italian in the journal "Rivista di Letterature Moderne e Comparate", LXXI (2018), vol. 3, April-June, pp. 269-290.

Among the few exceptions I aim to highlight is the critical monograph on Fortini written by J. Miszalska, Letteratura e impegno: la critica di Franco Fortini e la sua concezione della letteratura, Universitas, Kraków, 1993, the author of Polish translation of Traducendo Brecht (Ttumacząc Brechta [Translating Brecht], 'Dekada Literacka', 1995, no. 9, p. 9) as well as the article by K. Jaworska, Varsavia 1944: Franco Fortini e Stanisław Baliński, in: Italia Polonia Europa, scritti in memoria di Andrzej Litwornia, edited by A. Ceccherelli, E. Jastrzębowska, L. Marinelli, M. Piacentini, A.M. Raffo, G. Ziffer, Rzym, Polska Akademia Nauk w Rzymie, 2007, pp. 182-195. Some Fortini's poems were translated in English: Poems (transl. by M. Hamburger) Arc Publications, Todmorden 1978; Summer is not all. Selected poems (transl. by P. Lawton), Carcanet, Manchester 1992; Ten poems (transl. by E. Passannanti), Mask press, Kindle. Prof. T. E. Peterson (U. of Georgia), the author of the monography The ethical Muse of Franco Fortini (Un. Press of Florida, Gainesville, 1997), is actually working on a new translation of Fortini's poems. I wish to warmly thank him for the linguistic revision of this article. 
to have dedicated poems to the occupation of Poland as well as to the Polish Jews who fell prey to Holocaust, and to have paid particular attention to Polish culture. Here it is also crucial to remember that Polish was the first language of translation for his poems.

At the time of his political exile in Switzerland, among the crowds of emigrants coming from different parts of Europe, Fortini came across Polish refugees. In the text on Warsaw ghetto dating back to the 1990s he said:

I recall when I found myself in Zurich in the summer of 1944 as the Polish officers dressed in uniforms remaining from a military camp of internment passed by without looking at the groups of their Jewish compatriots from the nearby refugee camp (...)]. ${ }^{2}$

The reality of a far-off Slavic country must have interested the young poet even before the war as the center of dissemination of Jewish culture and the scene of anti-Semitic persecutions. Indeed, the 'horrible news that leaked from Central Europe ${ }^{3}$ spurred him to write two poems, titled Varsavia 1939 and Varsavia 19434, anonymously published in August 1944 in a Zurich magazine directed by Ignazio Silone. However, it is possible to imagine that the decision to write the two texts, inspired by either the invasion of Poland in 1939 or by the terrible fate of Polish Jews was also influenced by meeting both groups of internees.

Fortini came back several times to the two poems, defining them as 'imaginary translations". The first one dates back to the important preface to the $2^{\text {nd }}$ edition of Marching orders (1967):

[...] both texts titled Warsaw, characterized by such an ambiguous spiritualism (underlined by G.T.), as if they were translated from a non-existing Polish original. ${ }^{5}$

The tragic events of World War II encouraged Fortini to deal with historical events involving entire nations and civilizations prompting 'a growing verification of the individual in the collective history (as well as of a word in the language)'. ${ }^{6}$ This was not free from uncertainties and ambiguities, though. Let me quote the full text of these two poems by Fortini:

2 F. Fortini, Varsavia 1943. Passato e non passato, 'Il circolo', 1992, p. 4.

3 Id., Traduzione immaginaria, in: Id., Lezioni sulla traduzione, edited by M. Tirinato, Quodlibet, Macerata, 2011, p. 175.

4 'L'Avvenire dei lavoratori' 31/8/1944, p. 3. As we will see, Fortini will change the title Varsavia 1943 in Varsavia 1944 in the first issue of Foglio di via [Marching others].

5 F. Fortini, Prefazione 1967, in: Id., Tutte le poesie (henceforth TP), edited by L. Lenzini, Mondadori, Milano, 2014, p. 65

6 Id., Prefazione 1967, TP, p. 66. 
Varsavia 1939 [Warsaw 1939]

Noi non crediamo più alle vostre parole

Né a quelle che ci furono care una volta Il nostro cuore l'ha roso la fame

Il sangue l'han bevuto le baionette

Noi non crediamo più ai dolori alle gioie Ch'erano solo nostre ed erano sterili La nostra vita è in mano dei fratelli E la speranza in chi possiamo amare

Noi non crediamo più agli dèi lontani Né agli idoli e agli spettri che ci abitano La nostra fede è la croce della terra Dov'è crocifisso il figliuolo dell'uomo.] [TP, p. 16]

Varsavia 1944

E dopo verranno da te ancora una volta a contarti a insegnarti a mentirti E dopo verranno uomini senza cuore a urlare forte libertà e giustizia

Ma tu ricorda popolo ucciso mio libertà è quella che i santi scolpiscono sempre

per i deserti delle caverne in se stessi

statua d'Adamo, faticosamente.

Giustizia è quella che nel poeta sorride Bianca vendetta di grazia sulla morte Le mie parole che non ti danno pane Le mie parole per le pupille dei figli. [TP, p. 17]
[We no longer believe in your words] [And in those that we found dear once] [Hunger gnawed our hearts] [The bayonet drank our blood]

[We no longer believe in pains and joys] [That were only ours and sterile] [Our life lies in hands of brothers] [And the hope in whom we can love]

[We no longer believe in distant gods]

[Nor in idols or in ghosts living there]

[Our faith is the cross of the earth]

[Where the Son of Man is crucified.]

[Warsaw 1944]

[And then they will come to you once again] [to count you, to teach you, to cheat on you] [And then the heartless men will come] [to shout aloud freedom and justice]

[But you will remember oh my killed people] [Freedom is what the saints always carve]

[through the deserts of the caves in themselves]

[Adam's statue, painstakingly.]

[Justice is what smiles in the poet]

[White revenge of grace on death]

[My words which do not give you bread]

[My words for our children's pupils.]

Starting from their titles and the tone of an indignant accusation, they form the expression of an evident whole: after all, Fortini left them contiguous in all further reprints, starting from Foglio di via, in which they were inserted in 1946. Both of them are composed of free verses based on the hendecasyllable, inserted into 
a strophic scheme of non-rhyming quatrains. The classic formal structure, as rightly observed by Bernardo De Luca, has the function of counteracting 'the contents of high emotional intensity, [...] based on distance, not on emotion'. Recurring parallelisms, a search for a marked and percussive rhythm as well as of a metrical irregularity make both Warsaw poems nevertheless part of the experimental area. The definition of an imaginary translation provided by Fortini does not only cover an allusion to literary tradition, background or pretense that it could come from Poland occupied by Nazis, but it also considers the fact of re-echoing or parodying certain translation habits practiced in Italy. This places the two poems within the sphere of so called 'translation-like style', to which I will return shortly.

The two poems share some common features with other ones of Marching orders: a collective subject, an "abstract declamation" (following a suitable definition of the poet Giovanni Raboni), ${ }^{8}$ a juxtaposition of past/present/future, an oscillation between skepticism and hope connected to the nexus destruction-regeneration. ${ }^{9}$ The poems start and end with the term 'words' in two different meanings: one referring to bourgeois mystifiers, and the others, authentic ones, open to the future seen by the poet. ${ }^{10}$ Even though they have been built on key terms ('hope', 'faith', 'freedom', 'justice'), they are not capable of building a true monumentalism: the features of biblical and messianic rhetoric are mitigated by some skepticism which is used to describe Poles and Jews as more betrayed than able to fight.

In Warsaw 1939 Fortini opted for a choral chant structure and a first-person plural pronoun that will return in Sonetto [Sonet, a text dedicated to Holocaust]," in Coro di deportati [Chorus of deportees, also published in 1944 by 'L'Avvenire dei lavoratori'], in Canto degli ultimi partigiani [The Last partisans' song] as well as in Coro dell'ultimo atto [The Last Act - Chorus, TP p. 45, 18-19, 24 and 60]. The anaphoric use of 'we' is enhanced by its collocation in the incipit and, as I will try to show, this may result from heterogeneous literary heritage. It is also possible to ob-

7 B. De Luca, Foglio di via e altri versi. Edizione critica e commentata, Quodlibet, Macerata, 2018, p. 36. De Luca also notes that there is even a more glaring contrast between the form and the content present in Sonetto, where the issue of slaughter of the if very 'close to inexpressibility' (ibidem, p. 213).

8 G. Raboni, Temi resistenziali e "stile da traduzione" in Foglio di via, 'Paragone', 1980, issues no. 360-362, p. 166.

9 Cf. F. Diaco, Dialettica e speranza. Sulla poesia di Franco Fortini, Quodlibet, Macerata, 2017, p. 86.

10 When commenting on the later poetry titled Questo muro, Pier Vincenzo Mengaldo shrewdly pointed out that the distant future expressed by Fortini 'with as much more power, the less sure the result is' (P. V. Mengaldo, Un aspetto della metrica di Fortini, in: id. La tradizione del Novecento, Quarta serie, Bollati Boringhieri, Torino, 2000, p. 276).

11 In Sonetto the slaughter of Jews is narrated with non-naturalistic references to the stakes of the past: the chant of martyrs blends with an extradiegetic 'we' that appears just after the exhortation 'Friends, with them!'. 
serve a sort of intentional ambiguity (characteristic of Fortini's poetry), involving many different, even contradictory aspects. Francesco Diaco defines such a discordant alteration as an 'antithetic parallelism' where 'the first two lines of each quatrain deny the past, [...] while the last two ones turn to the present'. ${ }^{2}$ I would add that the present is also permeated by disillusion, emphasized at the beginning of every stanza with the insistent words: 'We no longer believe' ('in your words [...] pains and joys, [...] distant gods [...] idols nor spirits living there'). Moreover, what clearly emerges is the 'ambiguous spiritualism' disapproved by the poet in '67: the ambiguity results from messianic high concentration of 'biblical and existentialreligious language, merged with the socialist one'.13

As usual in Fortini, an individual experience (pains and joys / that were only ours and sterile') is contrasted by the collectively-shared one. The poet emphasizes the gruesome history lesson (gnawed hearts, drunk blood), without invalidating the hope in the future ('Our life lies in hands of brothers'), representing the leitmotif of his work of that time. In the last quatrain in which appear 'distant gods' and 'idols', the saving power of Christ enlightens in a fideistic manner human history. ${ }^{14}$ The poem, introduced by a strong declaration of disillusion, finishes with an unexpected remark of hope: it reaches, thus, an unpredicted 'apocalyptical and messianic overturning, thanks to which the catastrophe is overturned into a premise of redemption' ${ }^{15}$ Errors and disillusions are involved in the process of the selfconstruction of humankind: such a certain foretelling of salvation - as observed by Luca Lenzini - shows that it is 'always possible to improve the past, both the individual and collective one ${ }^{\text {'16. }}$.

Similar features appear also in Warsaw 1944 (also written in the first months of the same year) with a painful alternation of skepticism and hope. The anaphor of lines 1 and 3 reports mystification and betrayals not only in the present ('And then they will come to you once again / to count you, to teach you, to cheat on you/ And then the heartless men will come /to shout aloud freedom and justice' [underlined by G. T.]). Fortini opposes to evil an ascetic freedom, represented by the suffering of Man, Adam's son: the poet's words also imply a regenerating perspective for

12 F. Diaco, Dialettica e speranza..., cit., p. 117n.

13 The poet adds: 'I was not aware then of the deficiency of that confusion' F. Fortini, Un dialogo ininterrotto: interviste 1952-1994, edited by D. Abati, Bollati Boringhieri, Torino, 2003, p. 560. The messianism, as observed by Luca Lenzini, in Marching orders is expressed in 'an atmosphere wakefulness and vigil projected 'to an open and discontinuous time dimension' (L. Lenzini, Introduzione, TP, p. X).

14 Cf. D. Dalmas, La protesta di Fortini, Aosta, Sylos, 2006, p. 91 and F. Diaco, Dialettica e speranza..., cit., p. $117 n$.

16 Cf. L. Lenzini, Introduzione (TP, p. XXVI). 
'our childrens' pupils. ${ }^{17}$ As has been observed, the poet here refers to the close of the previous poem ('Where the Son of Man is crucified'): his ideal comparison between Adam and Christ is modeled on a famous passage from Epistle to the Romans $(5,14)$. Adam is a figura futuri, i.e. a figure resembling what or who was due to come, symmetrically to the Savior, "leading the humankind redeemed from the sin'. ${ }^{18}$ From Saint Paul's Epistle to Hebrews could also arise 'pains and joys / That were only ours and sterile' (Warsaw 1939), as well as mystical 'saints', 'deserts' and 'caves' (Warsaw 1944, vv. 6-7). ${ }^{19}$

Therefore, whilst reporting the tragedy of the present, the two poems also aim to represent it 'sub specie aeternitatis'. Among hidden literary 'retrievals' and intersections of Warsaw 1944 we can rank Il Natale [Christmas], by Manzoni, one of the most beloved Inni sacri (The sacred Hymns) by Fortini: it is also dedicated to the theme of Redemption, from Adam, father of a humanity marked by his 'fallo primo" ['first sin': A. Manzoni, Il Natale v. 16], to the Savior.

\section{Topics and people 'related to persecutions and conflict'}

Another common feature of the two Polish imaginary translations is the vague identity of the choral voice in Warsaw 1939 as well as the recipient of the appeal of Warsaw 1944. In the mid-war years, when the two poems were published anonymously, the only assured evidence were the titles referring to the historical dates and the name of the Polish capital. Nevertheless, it was not sufficient to

17 "The poet's words" are present also in Per un compagno ucciso [For a killed companion]; a similar function is played in Sonetto by a choral chant which 'sings an anthem that you steal from the night' (TP, p. 21 and 45). The perspective of the salvation of a new generation returns also in Per un compagno ucciso [For a killed companion]: 'We will guide the steps of our children / above the ground, more lenient than your death' (TP, p. 21).

18 P. Sabbatino, Fortini e la figura di Adamo. Il senso tragico della storia e della poesia, 'Otto/ Novecento', 14 (1990), issues no. 3-4, May-August, p. 74. Fortini quoted exactly the same passage from Epistle to the Romans at the conference Dei confini della poesia (1978, currently available in I confini della poesia, edited by L. Lenzini, Castelvecchi, Roma, 2015, p. 38), focused on the dialogue between tradition and modernity of a new poetry, able to 'understand and retrieve the dead, i.e. the past itself'.

19 'for none of us lives for ourselves alone, and none of us dies for ourselves alone.', Saint Paul, Romans 14,7; 'the world was not worthy of them. They wandered in deserts and mountains, living in caves and in holes in the ground.] Id., Hebrews, 11,38). The 'saints' appear in an other poem from Marching Orders, La gioia a venire [TP, P. 61 (The joy to come)], also dedicated to ambiguous promises of the future: 'The school of joy is filled with tears and blood/ /but also with eternity / And from the vanished mouths of saints / Like hedgerows in March there sparkles verity.' in F. Fortini, The joy to come, in: Id, Summer is not all. Selected poems (in Italian and English. Translated by Paul Lawton), Carcanet, Manchester 1992, p. 23. 
reasonably explain who were 'we' in the first one and 'my killed people' in the second.

Some critics speculated that both poems had been dedicated to the extermination of Jews. From my point of view, such an interpretation is difficult to support, particularly considering the final allusion to Christ in Warsaw 1939. After all, 1939 cannot refer only to the beginning of persecutions of Polish Jews with no reference to the invasion of Poland by Germans. It is unlikely that Fortini refers to the 'institution of Jewish ghetto' in Warsaw, as B. De Luca supposes ${ }^{20}$ considering that it was established in the autumn of 1940. In addition to this, both poems were conceived as imaginary translations from Polish: their hypothetical high-sounding original prototext quoting the New Testament, is difficult to connect with the Ashkenazi Jewish culture.

As far as the content is concerned, the specific reference to Christ in Warsaw 1939 may allude to messianic poetry of Polish Romanticism. Even if Fortini admitted not to knowing 'any single line, even translated' of Polish literature, ${ }^{21}$ it is unlikely that he could not have received any echo of the great Polish poet Adam Mickiewicz, renowned for his long exile, his patriotic activism and his imaginative dreams of a new Poland, which fascinated Giuseppe Mazzini. The myth created by Mickiewicz of Poland as the 'Messiah of the nations' was the top landmark of the Polish romantic poetry, translated into Italian, at least in rough translations, starting from the first half of the $19^{\text {th }}$ century $y^{22}$. After all, Fortini quoted the Polish poet in Verifica dei poteri, apropos of Herzen. ${ }^{23}$

Italian readers might therefore have expected from an anonymous poem translated from Polish a recurrence of a stereotype: prophetism and martyrdom were connected to Polish patriots' fight for freedom. The messianic dimension (which wasn't, nevertheless, a stranger to Fortini, describing himself as one who 'with his comrades / Now seeks the white roads of Galilee ${ }^{24}$ [Lettera, TP, p. 44]), allowed him to give more solemnity to a text connected with war and persecutions which concerned both Poles and Jews.

20 Cf. B. De Luca, Foglio di via..., cit., p. 24 and 123.

21 Id., Traduzione immaginaria, cit., p. 176.

22 Mickiewicz was the key voice of Polish romantic messianism: his drama Dziady (Forefathers' Eve) and Księgi narodu polskiego i pielgrzymstwa polskiego (Books of the Polish Nation and the Polish Pilgrimage, 1832) were translated into French and Italian in various editions. Other of his texts were issued during the interwar period in 'Rivista di cultura' (1924), in the Antologia della vita 7 (Rome 1925), as well as in numerous anthologies of world poetry. For complete reference of the Italian translations of Mickiewicz please see: Maria e Marina Bersano Begey, La Polonia in Italia, saggio bibliografico 1799-1948, Rosenberg e Sellier, Torino, 1949, pp. 81-96.

23 F. Fortini, Verifica dei poteri, in: Id., Saggi ed epigrammi, cit., p. 284.

24 Id, Letter, in: id., Summer is not all. Selected poems, cit, p. 21. 
It would therefore be appropriate to assume that the choral and soliloquizing voice of the Warsaw 1939 speaks on behalf of Poles, whereas Warsaw 1944 refers to slaughtered Jews. It is an abstract vision: Fortini liked to place the anti-Semitic atrocities in the more general context of what 'Nazis did by bringing suffering for the East-European peoples. ${ }^{25}$

In this light a clearly unnamed interlocutor of Warsaw 1939, whose words are no longer believable, might have been represented by 'accomplices of violence and oppression, who used to write in droves in Mussolini's ministers' journals during the months of Warsaw and Stalingrad siege'. ${ }^{26}$ 'Your words' vehemently accused of falsity might be addressed to Italy who shamefully signed the shameful "Pact of Steel" with the Third Reich, as well as to all the opportunists who observed with indifference the destruction and slaughters of Central-Eastern Europe.

I have already mentioned the title change of Warsaw 1943 renamed to Warsaw 1944 in Marching orders (1946). This fact, to which not much attention has been paid so far, has nevertheless an interesting prequel.

As Fortini himself recalled, both Warsaw compositions appealed to the members of Polish emigration who fell prey to his game of mystification. The poems were promptly issued by 'papers of Polish emigrants in London, Buenos Aires and New York'. ${ }^{27}$ Indeed, they appeared on the pages of 'Robotnik polski w Wielkiej Brytanii' [The Polish worker in the United Kingdom], the propaganda journal of the Polish Socialist Party in exile in London. Preceded by a short comment defining it as 'magnificent poetry dedicated to Warsaw translated from Italian', they were presented as unique texts split into two sections, each of them signed by respective date: Warsaw 1943 was nevertheless proofed to Warsaw $1944 .^{28}$ In the fall of ' 44 an analogous reference could remind the reader of the recent uprising held in the capital of Poland and its subsequent destruction a month later by German Nazis. It caused a misunderstanding which spread for decades. ${ }^{29}$ After all, the translator of both Fortini's poems into Polish, the Socialist poet in exile Stanisław Baliński,

25 Id., [Credibilità (Credibility), 1977], ibidem, p. 1056. In this article the poet remembers not wanting to believe, when being in 1944 in Zurich, in the existence of gas chambers as reported in a leaflet. This invective is from Fortini's 1967 preface to Marching orders: Id., Prefazione 1967, TP, p. 65. Id., Traduzione immaginaria, p. 176. Cf. Prefazione 1967, TP, p. 65.

Warszawa [with no indication of the author], 'Robotnik polski w Wielkiej Brytanii', 15/11/1944, no. 22, p. 1; cf. K. Jaworska, Varsavia 1944..., cit. p. 189. uprising of 1944 Warsaw Concerto. Powstanie warszawskie w poezji, edited by K. Kunert, Muzeum Powstania Warszawskiego, Warszawa, 2004, p. 581. A newer version of Varsavia 1939 by Anna Kamieńska, a poet and editor of 'Nowa Kultura' (a review that Fortini was in touch with), appeared in the anthology of foreign poetry titled Polska w poezji narodów świata: antologia wierszy o Polsce, edited by J. Śpiewak, PIW, Warszawa, 1959, p. 371). 
considered them 'one of the most beautiful treasures of Polish poetry', even though they were written by an Italian poet. ${ }^{30}$

We do not know if it was Fortini himself who changed the title or if he was only informed about it afterwards: it is however impossible not to observe its overlap with the change of the first edition of Marching orders (1946). Recalling the Warsaw ghetto Uprising held in April and May of '43, Warsaw 1943 might have suggested that its anonymous author was Jewish; Warsaw 1944 recalls instead the uprising of the Polish capital held a year later. It is however possible that the poet wished to demonstrate a higher (or vaguer) universality, in order to avoid identifying himself with Jews, especially when he publicly acknowledged the paternity of both 'Polish' poems.

The original date of 1943 and the appeal to 'my killed people' seems anyway to confirm Warsaw 1943/1944 to be a lamentation of Polish Jews. It is likely that Fortini tried to revise his painful embarrassment faced with 'small groups of Jews coming from Eastern Europe' met during the exile in Switzerland with their 'unacceptable [...] Kippur prayers screamed by people as if they were tortured and harassed', 'incomprehensible moaning and [...] long funeral dirges that penetrated the walls, while the forests remained completely mute and stunned. ${ }^{31}$ Perhaps, this situation blended with Fortini's image of his father, Dino Lattes, seen as a symbol of biographical failure, 'defeated day by day' (as described in the poem Lettera [Letter, TP p. 44]). ${ }^{32}$ Thus, it is no wonder that Warsaw 1944 assigned a totally passive role to 'my killed people'. Also in this poem, there occurs a resonant accusation of 'they', implied by strong and twofold 'And then they will come', threatening from the same incipit. The poet perhaps denounces people who mystify and remain indifferent towards the defeated's fate. As in other poems by Fortini, the end of war tainted by deception and treachery is foreshadowed. The strong pathos that fluctuates between suspicion and hope (offered by the poetwitness's liberating poetry) does not go as far as the aforementioned apocalyptic

30 That was written in a letter in English by Adam Ciołkosz, editor-in-chief of 'Robotnik polski w Wielkiej Brytanii', destined to Fortini via Tristano Codignola: "M. Balinski wishes Sign. Fortini to know, that he inserted quite purposely his poems at the close of the book, as he thought these two poems to be the most moving from among all the poems in this collection. (...) Please tell him also, that his poems belong now to the most beautiful treasure of Polish poetry." [Fondo Franco Fortini, Siena, 21/06/1950, 1 c. Sc. III, 54, 1]. Ciołkosz referred to having inserted the two poems by Fortini (merged in only one poem, titled Warszawa) in the poetic anthology by S. Baliński Wiersze zebrane 1937-1947 (Nakładem Stowarzyszenia Pisarzy Polskich, Londyn, 1948, pp. 299-300).

31 The passage of the Swiss diary of Fortini follows: 'We did not know well then what for. They only knew that at that time that behind the frontiers something, which will accompany us until the rest of our lives, happened.' (F. Fortini, Sere in Valdossola, Marsilio, Venezia, 1985, p. 8).

32 The writer defined his father as 'a person who was violently touched by history, politics, racial persecutions' with a 'personality of naive trust', Id., Un dialogo ininterrotto..., cit., pp. 238-239. 
descriptions in Sonetto ${ }^{33}$ : it even refers to Coro dei deportati [Chorus of deportees], published shortly before in the same 'L'Avvenire dei lavoratori' (TP pp. 18-19). The drama of those who were sentenced to death is also presented from a perspective of salvation. ${ }^{34}$

Now I would like to draw attention to other aspects of both poems. As in other texts of Marching orders, persecutions and conflict assume symbolic references, the epic 'is concise [...] and everything is reduced to a minimum and stripped' ${ }^{35}$ Among the tragedies of World War II Fortini seizes a universal value: it is no wonder that the background is reduced to a minimum. Regardless of their titles, references to the city, the Warsaw ghetto or the destruction of war are totally absent. This aspect cannot go unnoticed since other texts of Fortini that include in their titles some place names and years (Italy 1942, Basel 1945 [TP, pp. 14 and 22-23]) are not completely deprived of these descriptive details. Uniquely, the name of the Polish capital exposed in both titles, as well as the messianic allusions of the two final lines of Warsaw 1939 associate the background to Poland: the space is deprived of landscape, while the time is immersed in a transcendent perspective. Something of that kind occurs too in Valdossola (16 ottobre 1944, TP p. 20), a choral farewell to a partisan unit caught in a trap, whose lonesome defeat is set in a sort of emptiness, whereas the time represents the 'last act' in both individual and collective terms. In all three poems we can feel 'feelings of regret and sympathy' that are characteristic of Italian post-war civic poetry. ${ }^{36} \mathrm{After}$ all, one has the feeling that the tragic chorus of Warsaw 1939 and the people who the poet refers to as in Warsaw 1944 are all dead.

Warsaw 1939 and Warsaw 1944 are, thus, in line with the definition provided by Fortini about his own poetry, born 'from agitated metrical and lexical experiment with topics related to persecution and conflict'. ${ }^{37}$ As we can see, by introduc-

33 In Sonetto, also written in '44, the strongly symbolic features such as Dantesque echoes coexist with the chilling reports of a survivor expressed in the epigraph adjoined in ' 59 to Poesia ed errore). Quoted as a passage from Diario di una dodicenne polacca 1944 (TP, p. 45), it is effectively an excerpt from a diary of Janka (Janina) Hescheles (1931-) Oczyma dwunastoletniej dziewczyny [With the eyes of 12-year-old girl], published in Cracow in 1945 in Żydowski Biuletyn Historyczny [Jewish Historical Newsletter] in the volume issued in 1946; Fortini might have read its French edition (M. Borwicz, Écrits des condamnés à mort sous l'occupation nazie, 1939-1945, Paris, Puf, 1954) or perhaps heard about it from Alberto Nirenstein, the husband of his cousin Wanda Lattes, unwillingly detained in Warsaw until 1953.

34 Bernardo De Luca rightly observed that even in Sonetto the descent into hell is enlightened by the 'freedom of redemption' as well as by the 'destiny of rebirth' (Foglio di via e altri versi..., cit., p. 257).

35 C. De Girolamo, Ritratti di critici contemporanei. Franco Fortini, 'Belfagor', no. 3, 31/05/1977, p. 301.

36 F. Fortini, Disobbedienze II. Gli anni della sconfitta. Scritti sul Manifesto 1985-1994, Manifestolibri, Roma, 1998, p. 185.

37 Id., Per una piccola Enciclopedia della Letteratura italiana anno 2029, in: Autodizionario degli scrittori italiani, edited by F. Piemontese, Leonardo, Milano, 1989, p. 157. 
ing a sort of 'memorial mercy ${ }^{38}$, the two 'Polish' poems are open to interferences of the past and the present traditions.

\section{A Polish atmosphere?}

Fortini frequently recalled his encounter with minor texts of the French Resistance movement' during his exile in Zurich:

The geographical distance from Italy helped me out. At that time, I came across French Resistance's texts: I translated some of them by Éluard, Aragon, but also many other anonymous ones that were issued in a paper (very impressive ones) of Italian socialists in Switzerland which was in charge of Ignazio Silone."39

During those months, on the pages of this same paper 'L'Avvenire dei lavoratori'), Fortini published his translations and poems inspired by the war, including the two apocryphal 'Polish' texts:

In 1944 in Zurich I released several versions of Cassou, Emmanuel and Éluard in a Socialist paper; subsequently I published two poems of mine, anonymous as if they were translated from Polish. ${ }^{40}$

It is no coincidence that these two compositions took their names after Warsaw [...] they were pretending to be translated from a non-existing Polish original. That was 'translation-like style' that swept through later on. [...] It was a sign of an uneasiness, destined to grow. [underlined by G.T. ${ }^{41}$

With a leap of logic ('It is no coincidence...'), the preface of 1967 implicitly acknowledges the connection between the imaginary translations of ' 44 and the real ones belonging to French anti-Fascist poetry published in 'L'Avvenire dei lavoratori'. Indeed, as we can observe also in Paul Éluard's poems, in both Warsaws we can find 'a percussive pronunciation' that, as remarked by Giovanni Raboni with regard to Coro dei deportati [Chorus of deportees] manifests in 'rhythmic and sound measure of basic syntactical links or [...] of single words. ${ }^{42}$

38 The definition is taken from Fortini's article on Shoah (F. Fortini, Varsavia 1943. Passato e non passato, cit., p. 42).

39 Id., Un dialogo ininterrotto, cit., p. 461.

40 Id., Premessa [a] II ladro di ciliegie, TP, p. 737.

41 Id., Prefazione 1967, TP, p. 65.

42 G. Raboni, Temi resistenziali..., cit., p. 166. Anna Manfredi wrote of an important 'stylistic and ethical model' provided by Éluard and applied for numerous Marching orders's poems (A. Manfredi, Fortini traduttore di Eluard, Pacini Fazzi, Lucca, 1992, p. 5). 
Both Warsaw poems describe a situation without return, a story of injustice and solitude (yet not desperation) of defeated and slaughtered people, without excluding a prospect of freedom. The persistent 'we', repeated at the beginning of every quatrain of Warsaw 1939, might be an echo of the intense choral nature of $\mathrm{La}$ dernière nuit, translated by Fortini for 'L'Avvenire dei lavoratori' (10/05/1944). Let me take into consideration its final section:

Nous jetons le fagot des ténèbres au feu

Nous brisons les serrures rouillées de l'injustice

Des hommes vont venir qui n'ont plus peur d'eux-mêmes

Car ils sont sûrs de tous les hommes.

Car l'ennemi à figure d'homme disparait.

translated into Italian in the following by the poet:

Noi buttiamo nel fuoco il sacco delle tenebre

Noi spezziamo i serrami di ruggine dell'ingiustizia

Ecco uomini vengono.

Che non hanno più paura di se stessi.

Perché sono sicuri d'ogni uomo

Perché il nemico dal viso d'uomo sparisce. [For the enemy with a human face disappears.]

[We throw the bag of gloom to the fire]

[We break the rusted locks of injustice]

[Men will come]

[Who no longer fear themselves]

[For they are sure of every man]

$$
\text { disappears.] }
$$

(TP, pp. 716-717)

A percussive pronunciation, caused by a syntactic iteration, also re-echoes in Fortini's imaginary translations: in the v. 2 of Warsaw 1944 ('a contarti a insegnarti a mentirti') we can observe a decasyllabic verse, so-called decasillabo manzoniano, as well as a coherent iambic pentameter in the incipit of both texts (Warsaw 1939: 'Il nostro cuore..., 'La nostra vita è in mano ai fratelli', 'La nostra fede...'; Warsaw 1944: 'E dopo...,'E dopo...;'A urlare...'; 'Ma tu ricorda..., 'Giustizia...']). ${ }^{43}$

Perhaps it was just Èluard's diction, strongly pronounced and based on parallelisms and repetitions, that helped Fortini to create a sort of counterbalance to the messianic emphasis of the two "Polish" poems? It is possible that the phantasmal shade of Warsaw 1939, suspended between reality and dream, survival and death (the blood 'drunk' by old-fashioned bayonets) may be legitimately regarded as an irradiation of La dernière nuit, where a 'murderous little world' [petit monde

43 De Luca defined the use of the linking word 'and' at the beginning of a line as 'a sort of Fortini's stylistic twitch' (B. De Luca, Foglio di via e altri versi..., cit., p. 290). 
meurtrier] "confounds the dead and living?" (TP, p. 713). Anyway, as I have already observed, the author of Warsaw 1939 is not, however, sure about humanity's probity in the future: his choral chants from Marching orders are mostly sung by losers rather than by winners, even though they rely on the message of hope and redemption in the future.

French poetry is not the only one evoked by the two imaginary translations from Polish. Fortini, when self-commenting on own metrical-prosodic model, observed that:

there are two forms, both equally inauthentic or at least poorly controlled: the first one had an apparent epigraphic immediacy, like a sort of password, sob or scream; the latter implicated some literary artifice and deliberate archaism. I believe that almost all of my poems published between 1940 and 1955 fall into one of two metrical-prosodic structures: on one hand Ungaretti-style syllables, proclamations, manifestos, verses which seem to be intentional translations from Germanic or Slavic languages [underlined by G.T.], on the other sequences of hendecasyllable, hendecasyllabic and heptasyllabic stanzas, rhymed quatrains, even regular sonnets, long strophes and complex rhymes. ${ }^{44}$

The general reference to Germanic and Slavonic model became clearer a few years later in Traduzione immaginaria:

In Zurich, in the first months of ' 44 [...] I had an urge to write poetry allegedly being a translation from imaginary Polish original. [...] I had in mind lines composed of between eleven and fourteen syllables. (I got inspired - I think I can say - by examples of translations deriving from Russian poetry, probably made by Renato Poggioli, who published them in journals of the time when I lived in Florence). However this instinctive imitation was characterized by an impassioned, prophetic and emphatic tonality, mediated too by translations (underlined by G.T.) with appeals to 'my killed people' as well as to a kind of 'tragic Christianity' of 'martyrs of the nations. ${ }^{45}$

At a time when the author turned to 'Polish' topics, he came out with vague echoes of Slavic translations. Publishing his work in 'Solaria', 'Letteratura' and 'Campo di Marte' ${ }^{46}$ Poggioli had tried to retain some aspects of Russian syllabo-tonic verse,

44 Id., Metrica e biografia, 'Quaderni piacentini', no. s., 7 (1981), no. 2, p. 111, currently available in I confini della poesia (2015), cit., p. 54.

45 Id., Traduzione immaginaria, cit. pp. 175-176.

46 With regard to these legendary rewies Fortini recalled: 'In Florence around 1935 in 'Frontespizio', or in 'Campo di Marte' or in 'Letteratura', who was not a translator at that time?' [Id., Preface to Ladro di ciliegie, TP. p. 737]. 
especially with regard to iambic rhythm, scarcely frequent in Italian prosody. ${ }^{47} \mathrm{His}$ translations from Polish concerned works in prose only, though.

Fortini monitored with particular attention the intense translation activity of Poggioli, collected in La violetta notturna (1932) as well as in the renowned Fiore del verso russo (1949). In a critical review of the latter anthology, Fortini accused Poggioli of being stubborn in 'transferring meters and rhythms from another language into apparently similar Italian meters' and of having selected 'an Italian lexis with no time and history', in line with the 'linguistic neo-classicism of the Hermetic experience' ${ }^{48} \mathrm{His}$ disapproval concerned many other translators of the ' 30 s and ' 40 s, who (the same way as he did) denied 'the positive crisis of literary language [...] in Italy' ${ }^{49}$ Their choices were contrasted by the author of Marching orders with an idea, already proposed by Walter Benjamin, of interlinear translation, enriched by a 'metrical scheme' and a broad system of footnotes; that was a criterion that - he concluded impatiently - 'it might be time to be applied to lyrical translations.. ${ }^{50}$

It is clear that by referring to Poggioli Fortini intended to allude to the so-called 'translation-like style', a term frequently used and perceived in its pejorative connotation: 'the crushing and mortifying influence [...] performed by one or another foreign poet' on Italian poets' verses 'redone in often dull translations'. ${ }^{51}$ It is not accidental that two other poems written in the Swiss period (Per un compagno ucciso [For a killed companion] and Coro per un ultimo atto [The Last Act - Chorus]), were also considered by Fortini as contaminated by some translations of the '30s

47 Cf. L. Organte, Poesia e traduzione a Firenze (1930-1950), Libreraiauniversitaria.it, Padova, 2018, passim; G. Ghini, Tradurre il ritmo del poeta. Puškin nelle "versioni ritmiche" di Renato Poggioli, 'Studi Slavistici', II (005), pp. 81-9. For other cooperation of early Poggioli who, starting from the mid '30s, worked in Praha, Vilnius and Warsaw, see also in A. Cristiani, Renato Poggioli e le riviste fra le due guerre, 'MediAzioni', 5, http//mediazioni.sitlec.unibo.it.

48 Id., Un'occasione mancata. II fiore del verso russo, 'Avanti!', 3.12.1949, p. 3. Fortini seems to anticipate his critical observations published a few decades later in Giudici traduttore dell'Onegin: F. Fortini, La "letterarietà" della traduzione, in: Id. Lezioni sulla traduzione, cit., p. 188 et seq.

49 Id., Un'occasione mancata, cit., p. 3.

50 ibidem. The author of Questo muro in later years continued to appeal to the necessary 'interpretative humility" of interlinear translation (cf. Traduzione e rifacimento, in: Id., Saggi ed epigrammi, cit., p. 820-822; Lezioni sulla traduzione, cit., passim). For criticism of R. Poggioli's translations cf. S. Savioli, La curiosa fortuna del Fiore ovvero note sulla recezione critica, in: C. Pavese, R. Poggioli, A meeting of minds: carteggio 1947-1950, edited by S. Savioli, Edizioni dell'Orso, Alessandria, 2010.

51 This definition was by E. Falqui ([introduction to] La giovane poesia. Saggio e repertorio, Carlo Colombo, Roma, 1957, p. 73). Paolo Giovannetti defined the 'translation-like style' as 'a sort of false metrics', where 'the foreign model justifies the intemperance of the form [...], creating its physiognomy in an inacceptable way.' (P. Giovannetti, G. Lavezzi, La metrica italiana contemporanea, Carocci, Roma, 2010, p. 299). 
and '40s (and subsequently 'cleared' from those accusations by Raboni). ${ }^{52}$ It is obvious to me that at least in the two poems dedicated to Warsaw the contamination from translation-like style was not the result of an involuntary 'picking up'. On the contrary, I believe that Fortini's 'Slavic' experiment alluded to translation stylistic features by Poggioli as a possible building material in the same way as he adopted in his poetry these same 'limping' hendecasyllables, that 'were all the rage both by the right-wing as well by the left-wing of lyrical hemicycle'.53

I would not rule out the possibility that in the first lines or hemistiches of three quatrains of Warsaw 1939 ('We no longer believe in your words [...] We no longer believe in pains and joys [...] We no longer believe in distant gods) we can see an embedded echo of Plebs by Pushkin, translated by Poggioli shortly before the war. He translated Pushkin's iambic tetrapody in nine-syllable lines with a regular iambic rhythm. The first-person plural personal pronoun recurs two times when the plebs declared: 'We are wicked and insolent', while the snobbish poet replied: 'We weren't born for the action ${ }^{34}$. If it was so (without excluding references to other versions translated from Russian by Poggioli), then we could think that already in 1944 the same uneasiness caused by 'translation-like style' could have helped Fortini to find new 'words' and forms. They might have launched the work on his first imaginary translations by bringing on further reflection on relationships between language translation and contemporary poetry's development. ${ }^{55}$

\section{'For the sake of trial'}

The occurrence of important topics in Fortini's poetry, such as World War II and the Shoah, makes us forget that the two Warsaw poems are apocrypha, born as a free experiment deriving from a hypothetical foreign model and from a specific translationlike style. It shall not be useless to recall a few thoughts of Fortini on literary hoaxes.

In 1989 the poet provided a list of his own imaginary translations: the two 'Polish' poems, Via dello Yenan [The Road to Yenan] (smuggled into 'Il Politecnico'

52 F. Fortini, Prefazione 1967, TP, pp. 65-66; G. Raboni, Temi resistenziali.., cit., passim.

53 In the same sentence Fortini, when quoting La giovane poesia by Falqui, recalled how the 'rhythmic of translation' was 'rightly mocked' in 1945." It is clear that the poet referred too to Marching orders and counts on the 'metrical consciousness' of his prudent reader, capable of recognizing allusive references to those 'limped' hendecasyllables: (F. Fortini, Su alcuni paradossi della metrica moderna, in: Id., Saggi ed epigrammi, cit., p. 816).

54 A. Pushkin, La plebe, traduzione metrica dal russo, by R. Poggioli, 'Campo di Marte', II, no. 9 , $1-15.05 .1939$, p. 3. Poggioli had already commented and quoted the poetry in his article titled Puskin lirico, 'Letteratura. Rivista trimestrale di letteratura contemporanea', 1 (1937), no. 3, p. 128-129.

55 On the one hand the poet used the term 'translation-like style' in the negative sense, but on the other he highlighted the positive influence of the new translations (also in prose) on the vocabulary of the new poetry in the interwar period (cf. Prefazione 1967, TP, pp. 65-66). 
as a translation from 'Chinese'), a translation from English Il cardinale [The Cardinal] ('with a tonality between Archibald Mac Leish and Stephen Spender'), an 'apocryphal octave of Monti's version of The Maid of Orleans by Voltaire', 'alexandrines echoing the epoch of Ronsard', ${ }^{56}$ 'a parody of Parini's theme', 'the imitation of two sonnets by Gongora'. These references might be integrated with other Fortini poems and the list still will not be complete. ${ }^{57}$

As the imaginary translations are contiguous with imitation, remake, parody and allusion (in terms of form and contents), Fortini acknowledged that such an experience had influenced his own "second purpose" poetry, inspired by Milton, Tasso, Brecht, as well as Sestina a Firenze, re-echoing the older tradition of sestina. Especially in his translation of Milton's Lycidas, there occurred a sort of 'insertion or adaptation 'of the real translation into the imaginary one'. The poet even glimpsed some elements of imaginary translation in a few early novellas of Landolfi and Cassola ('a parodist treatment of stylistic elements taken from mediocre French and Russian novelists' ${ }^{58}$ and even in Pasolini's poetry, where some references to Troubadours' poetry are present. ${ }^{59}$

I would like to add that in Cinque paragrafi sul tradurre (Five paragraphs on translation, 1972) we can observe a few important remarks on 'a variation starting from patterns' which help us understand Fortini's concept of imaginary translation. The variation occurs in a translation, when 'the same sequence of communicative content' is transferred into 'a completely different syntactic and metrical construction', instead of mechanically reproducing the metrical structure of the original text:

The pleasure that [an imitation, a parody, a remake note of GT] creates is the variation within the context of a repetition. For further steps we can translate writing in the manner of the author or reproduce a single element using another key. ${ }^{60}$

A similar game is feasible as long as we can safeguard the 'deep need' of transferring experience, i.e. the knowledge-based legacy, being so crucial in a world sworn to 'the radical destruction of every 'memory of one's own'. Fortini, in order to explain this conception, used a very interesting metaphor, that of a man who:

56 As implied by Mariavittoria Tirinato, Fortini probably referred to the composition Au Sieur E. D. A., qui avait blâmé la vanité de l'Auteur, currently available in Saggi ed epigrammi, edited by L. Lenzini, Mondadori, Milano, 2003, p. 1045.

57 Id., Traduzione immaginaria, cit., pp. 176-178. Da un canto ungherese 1915-1918, Traduzione immaginaria, Altra traduzione immaginaria (TP, p. 757 e 773-774), Traduzione immaginaria da Mallarmé (currently available in Id., Saggi ed epigrammi, cit., p. 1066).

58 Id., Traduzione immaginaria, cit., p. 177.

59 Id., Traduzione e rifacimento, p. 828.

60 Id. Cinque paragrafi sul tradurre, in Id., Saggi ed epigrammi, cit., p. 840. 
is going through the ruins of the city where his house was, looking for anything that survived after the destructors, for the purpose of using it someday as a building material. ${ }^{61}$

Fortini seems to allude to the magmatic process of 'changes and destructions' induced, also in the cultural area, by historic development. ${ }^{62}$ For him the most interesting features of modern translation - real or imaginary - have a defamiliarizing, deconstructivistic character of decomposition and recomposition. The form creatively dissociates from the foreign original, while in the target-language text the 'recovery material', both lexical and formal, is used (including the one coming from the so-called 'Authors' memory' of the translator). ${ }^{63}$ Between the latter and the translation it opens indeed a huge, decisive 'intermediate zone' created by fundamental 'register shifts'.

The translation aims to open up to different references creating a system of sometimes concealed intersections and allusions where literary associations and combining devices play a leading role. From my point of view, the metaphor introduced in Cinque paragrafi sul tradurre, showing poetry as a sort of mixed masonry, also represents the essence of the imaginary translation, which, as Fortini declared, is conceived 'for the sake of mocking joke or trial' and 'contiguous with imitation or parody ' ${ }^{64}$ It is therefore a text with open frontiers, full of intertextual cross-references to the culture of the target language, which can be more numerous than the ones belonging to the foreign tradition inspiring it (or just pretending to inspire).

Let us consider the latter imaginary translations of Fortini: both the ones in which the poet reveals the source text in their title and the ones in which he challenges the reader to take all the allusions disseminated in form and content. Traduzione immaginaria da Mallarmé [Imaginary translation from Mallarmé] alludes to the pastoral atmosphere of Après-midi d'un faune, not only with an unexpected lexical choice ("quercia", "pastore", "sufolo", "bosco" [oak, shepherd, zuffolo, wood]), but also in its specific form: an octosyllabic sonnet, used by the Arcadia poets for idyllic pastoral topic.

Traduzione immaginaria [Imaginary translation, TP p. 773] thematically refers instead to Lais on Eliduc and Tristano by Marie de France: it is composed in hendecasyllables with very irregular rhyme, while the subsequent Altra traduzione immaginaria [Another Imaginary translation, TP pp. 773-774] entrusts to free verse with a hendecasyllabic structure a narration of ancient perilous navigations in the

61 Id., Traduzione e rifacimento, cit., p. 838.

62 Id., Metrica e Autobiografia, cit., p. 41.

63 'We have to place ourselves in a tradition which will work for us': Id., Traduzione immaginaria, cit., p. 179.

64 Ibidem, p. 175. 
Southern Hemisphere. By presenting his imaginary poems in a metrical structure known and significant to an Italian reader, the poet pushes him to look over the frontiers of their non-existing prototext, investigating parodic allusions and intentions, including the ones related to certain contemporary translation customs. This seems to occur in the 'Polish' imaginary translations, where the apocryphal mystification might also refer to the stylistic choices of some translators who transplant certain Slavic metrical forms into hendecasyllables, the principal metre in Italian poetry. Among their numerous references, imaginary translations include therefore an implicit meta-discourse on translation.

\section{'Manzoni also was a Polish poet'}

Nonetheless, the 'rascally trick'65 of imaginary translations reiterated a distinguished literary tradition, that includes Ossianic poems by James Macpherson and Inno greco a Nettuno [Greek anthem to Neptune] by Giacomo Leopardi. In the midst of WWII, Polish mystification was somehow a little bit easier: the brutal German occupation turned Poland into an ubuesque country, that is to say 'Nowhere': so a foreign reader was keen to accept any of its representations, even the most abstract or symbolic.

Anna Manfredi noticed that Fortini's poetry implicated the idea of 'a literary audience, at least until the $20^{\text {th }}$ Congress of the CPSU. ${ }^{66}$ In 1944 his audience was composed of Italian partisans and European exiles reading 'L'Avvenire dei lavoratori', a journal published in Zurich by Ignazio Silone. I would like to remind the reader that on page 3 of the same issue of 'L'Avvenire dei lavoratori' dating back to August 31, 1944, the two Warsaw poems were followed by an anonymous review of a Stephen Spender essay, quoted with a French title, La guerre et l'expérience poétique en Angleterre et en France. In this review, the French poetry of Aragon, Émmanuel and Éluard, as well as the English one of Comfort, Hendry and Treece was defined as 'the voice on common war, on solitary war, waged to defend the cause of the world which is waiting to be born'. The article, perhaps written by Fortini himself, concluded, appealing to people who had the possibility:

let them read the work of these poets, who suffered, hoped and wrote for others.

Perhaps even in Italy some are seeking new words rooted in the comrades' hearts. ${ }^{67}$

In the context of this appeal, comparable to others which the poet composed at that time, the proposition of two 'Polish' poems, characterized by 'impassioned,

65 Ibidem, p. 177

66 A. Manfredi, Fortini traduttore... cit., p. 17.

67 Poesia 1944, 'L'Avvenire dei lavoratori', 31/08/1944, p. 3. 
prophetic and emphatic tonality' as well as by solemn messianic references to both Old and New Testament, may seem paradoxical. It may be much less paradoxical, if we consider the heterogeneity of the 'building material' which represents the basis of 'new words' and connects the ideals of the present and of the past.

With his imaginary translation of two unreal Polish originals, the poet introduced new rules. He declared (though we may choose not to believe him), that he did not know 'even a single line' of that literature, (that is just why an imaginary translation from Polish could have been attractive to him). Not only the presentation of unknown poems, whose paternity was not verifiable in the midst of WWII, but also their Polish heritage, still little-known in Europe, gave Fortini much greater freedom. The painful historical current events set him free from referencing the author's name and respecting the style and metrical forms typical for Polish contemporary poetry (he will get in touch with it only in the mid '50s). ${ }^{68}$ In such an unusual condition, completely different than from his later imaginary translations, Fortini enjoyed an extensive freedom of movement, not only completely free from any ' $[. .$.$] discussions on fidelity, equiva-$ lence [...]', but also from any 'knowledge of culture of the source language', ${ }^{69}$ which in other conditions would be indispensable for a translator.

As already said, the two Warsaw poems might resemble other poems of Marching orders in terms of formal and stylistic features (the search for an accented rhythm, recurring parallelisms, choral emphasis) as well as of the contents (the vehement Resistance-style denunciation, aptly seen by the critics, the accusatory invective). Other aspects, in turn, are characterized by specific features: 'tragic Christianity as martyrs of the nations', references to St. Paul and $19^{\text {th }}$-century solemn vocabulary ('distant gods, 'idols', 'my people'). Warsaw 1939 refers to the poetic tradition of the previous century in terms of tone modulations and other more complex allusions. Add to this translators from Slavonic languages, connected with the Hermetic poetic movement, as well as Poggioli himself.

This all lends to Fortini's first literary hoaxes the shape of 'compilation'. ${ }^{70}$ As a matter of fact, they betray the promises suggested by their titles: they are not true

68 Fortini published in an anthology dedicated to Resistance the Italian translation of two Polish poems, Elegia o chłopcu polskim [The Elegy for a Polish Boy] by Krzysztof Kamil Baczyński, died at the age of 23 in Warsaw Uprising, and Kawiarnia [The coffeehouse] byt Czesław Miłosz: K. K. Baczyński, C. Miłosz, Un caffè, in: La Resistenza nella Letteratura. Antologia, edited by A. Marchetti and G. Tassinari, La Base, Milano, 1955, p. 27 and p. 159-161 (the translation was made by Christina Fuhrman, an enigmatic collaborator of the author of Marching orders). Some lines of Mitosz's The coffeehouse have inspired the title of a short prose by Fortini issued in 1964, I massageti (F. Fortini, Saggi e epigrammi, cit., p. 979).

69 F. Fortini, Lezioni sulla traduzione, cit. p. 98.

70 By using this term, I intend the combined and intertextual character of the two imaginary Polish poems. I do not share the opinion of Paolo Giovannetti, who defined Warsaw 1939 as a 'compilation of biblical parallelisms' (P. Giovannetti, G. Lavezzi, La metrica italiana, cit., p. 54). 
Resistance poems, as they skip any non-metaphorical reference to the persecution and partisan struggle against invaders of Poland. From my point of view, their 'ambiguous spiritualism', mitigated by a certain sorrowful skepticism, is also the result of an experiment that juxtaposes and compares different topics and stylistic registers, converging different influences and tending to reach a modulation of composite tones.

We should not forget that the two "Polish" poems, which many years later Fortini himself will disapprove as 'average and vehement', ${ }^{71}$ were a reaction to 'the horrible news that leaked from Central Europe', which was difficult to believe. Fortini felt an urgency to create a new tradition of Italian poetry on war and persecutions: an unusual prophetic register that results from linguistic choices, anaphora and biblical references. This provides evidence that the author was inspired, with combinational intention, by Italian $19^{\text {th }}$-century civic poetry. It might be useful to quote his declaration dating back to 1982 :

Some books connected to a University course that I teach, drove me to the romantic national poetry of the first half of the $19^{\text {th }}$ century, when, so to speak, Manzoni also was a Polish poet. That is the time and the source of lots of engaged poetry of the first half of the $2 \mathrm{O}^{\text {th }}$ century. I even believe that it is necessary to take a better look at the very complex relationships between this ever resurgent 'genre' and its target audience. [underlined by G. T.]. ${ }^{72}$

It does not seem accidental to me that the author of Verifica dei poteri compares Polish romantic poetry to Manzoni, his beloved poet, who had embedded in his Inni sacri several biblical allusions. Having probably in mind some echoes of Polish messianism, Fortini speaks about Poland referring at one time to his own 'Authors' memory' ${ }^{73} \mathrm{He}$ suggestively notices some complementarity between $19^{\text {th }}$ century Polish and Italian culture, combining them in an ideal consonance. In his two "Warsaw" poems the topic of faith and messianic redemption and the game of 'spoken and unspoken'74 perfectly fit into an ideal connection that joins Polish and Italian traditions, both of the present and of the past. Fortini doesn't presume a direct influence of Polish literature on the Italian one:

71 F. Fortini, Traduzione immaginaria, cit., p. 176.

72 Id., Libertà vo cercando [annex to 'Manifesto'], Edizioni del Manifesto, Roma, 1982, presentation of the translation of A. Ważyk's Poem for adults (reprinted with the title La libertà del silenzio della poesia, in: Disobbedienze II, cit., p. 265.

73 For this form of deference to literary tradition, see Fortini's observations of Traduzione e rifacimento, in: Id., Saggi ed epigrammi, cit., p. 822 et seq.

74 See also the observations of Mengaldo on the role of allusion in the literary culture of the $20^{\text {th }}$ century, with particular regard to Fortini's poetry in: P. V. Mengaldo, Allusione e intertestualità: qualche esempio, 'Strumenti critici', 2015, no. 3, pp. 381-404, passim. 
his experiment represents instead a sort of corollary to an intricate 'grafting" of two distant, but at the same time interrelated, cultures. The same heterogeneity of this operation safeguards against rhetoric. Moreover, as I have already noted, both imaginary poems are far from the messianic faith for justice, that nurtured Polish romantic poets in exile.

I believe that all this meant for Fortini a sort of creative reaction, as admitted by the poet himself, caused by prolonged moments of annoyance towards his own 'metrical and stylistic identity'. ${ }^{75}$ Fortini reacted to this annoyance by aiming to research other cultural stimuli and voices during his whole poetic career. ${ }^{76}$ Irene Fantappiè so acutely noticed that translating allowed him to alternate a series of 'author's masks', ${ }^{77}$ in order to guarantee his poetry a capacity of dynamic regeneration.

By imagining a Polish militant poetry, the author of Marching orders expressed once again his solidarity with History's losers. He not only chose two cultures connected in the $19^{\text {th }}$ century by the stereotype of the fight for liberty, but also investigated their potential intersections with contemporary French civic poetry. He also carried out research into connections between his own culture and 'Authors' memory' and an ideal Polish Resistance poetry, which was yet unknown in the West, but so necessary that it should be imagined.

The two imaginary translations perfectly overlapped the new civic Italian poetry, which Fortini was promoting: moreover, they reflected the tendency to match and merge styles and voices, that would mark all his poetic and translation work, when he would translate not only his 'elder brothers' (Éluard, József, Vallejo, Hernández, Brecht), ${ }^{78}$ but also other unknown and imaginable poets.

The encounter with Polish authors sharing with him the dream of a better world definitely represented for Fortini a form of 'resistance to some of History's

75 Id., Prefazione, in: L'Ospite ingrato: primo e secondo, Quodlibet, Macerata, 2003, p. 8.

76 In a letter to Edoarda Masi of 1973, Fortini mentioned his own ways of feeling time as a 'moment of decreased identity or of an appearance of a new identity: a moment of other people's voices which are going through me.' (Id., L'Ospite ingrato primo e secondo, cit., p. 253).

77 Cf. I. Fantappiè, Cinque tesi sulla traduzione in Fortini, Sélection e marquage in II ladro di ciliegie, Letteratura italiana e tedesca 1945-1970: Campi, polisistemi, transfer Deutsche und italienische Literatur 1945-1970: Felder, Polysysteme, Transfer, edited by I. Fantappiè and M. Sisto, Istituto Italiano di Studi Germanici, Roma, 2013, http://www.germanistica.net/2014/04/30/cinquetesi-sulla-traduzione-in-fortini-selection-e-marquage-in-il-ladro-di-ciliegie/. In Confini della poesia Fortini recalled that 'writing poems is not attributable to any specific identity [...]. The work is written by someone else or even by no one.' F. Fortini, I confini della poesia, cit., p. 48.

78 Fortini wanted to remind that several new rhetorical 'figures' of Marching orders 'were written, or more precisely, in those same days when other ones were being written by Jozsef, Machado, Brecht, Hernandez, Auden, Radnotj, Vallejo. Without knowing it, the author communicated with a multitude of unknown elder brothers.' (F. Fortini, Prefazione 1967, TP, p. 67). 
disappointments ${ }^{79}$. It is not accidental that just after the crisis opened by the $20^{\text {th }}$ Congress he launched an ambitious project of an Anthology of protest and rebel poetry, which comprised around sixty texts translated from Polish and Yiddish. ${ }^{80}$ A year later he dedicated to another translation from Polish poetry (this time a real one and set in real Warsaw): Poem for Adults, by Adam Ważyk, the text that inaugurated the post-Stalinist Polish 'Thaw'.

(translated from Italian by Łukasz Jan Berezowski)

\section{Bibliography}

Cristiani Andrea, Renato Poggioli e le riviste fra le due guerre, 'MediAzioni', 5, http:// mediazioni.sitlec.unibo.it.

Dalmas Davide, La protesta di Fortini, Aosta, Sylos, 2006.

De Girolamo Costanzo, Ritratti di critici contemporanei. Franco Fortini, 'Belfagor', no. 3, 31/05/1977, p. 301.

De Luca Bernardo, Foglio di via e altri versi. Edizione critica e commentata, Quodlibet, Macerata, 2018.

Diaco Francesco, Dialettica e speranza. Sulla poesia di Franco Fortini, Quodlibet, Macerata, 2017.

Falqui Enrico, La giovane poesia. Saggio e repertorio, Carlo Colombo, Roma, 1957.

Fantappiè Irene, Cinque tesi sulla traduzione in Fortini. Sélection e marquage in Il ladro di ciliegie, Letteratura italiana e tedesca 1945-1970: Campi, polisistemi,

79 Such a self-ironic comment was made by Fortini in the above-mentioned encyclopedic article about himself: 'The lyrical work of $F$. has undergone the stage of uncertain and complex resistance to History's disappointments' (F. Fortini, Per una piccola Enciclopedia della Letteratura italiana anno 2029, cit., p. 157).

80 The signs of the huge project, put forward to the publisher Vallardi, were included in a letter sent to Enrico Falqui in January 1958 (Letter of F. Fortini to [Enrico] Falqui, Fondo Franco Fortini, Siena, 1 c. Sc. XXVI, 75,) as well as to another collaborator of the publishing house, Giacomo Zanga, to whom the poet declared 'with great regret' not to be able to complete Poesia della protesta e della rivolta 'finished in three fourths [...], thanks to precious help of my wife'. This was supposed to contain 400 pages of text with an introduction of 30-40 pages. The translations from Polish and Yiddish were made by the already mentioned Alberto Nirenstein (A letter dated 22/1/1960 to G. Zanga, Fondo Franco Fortini, Siena, Fortini-Zanga, Sc. XXIX, 48).

81 This four-handed translation, by Fortini and the aforementioned Christina Fuhrman, was published in 1957 by 'Ragionamenti': cf. my article, approaching the issue of Fortini's contacts with Polish culture: G. Tomassucci, Una traduzione dimenticata: 'Poesia agli adulti' di Adam Ważyk, in: Per voci interposte. Fortini e la traduzione, edited by F. Diaco, E. Nencini, Quodlibet, Macerata, L'ospite ingrato, 2019, [monographic issue dedicated to F. Fortini], pp. 45-65. 
transfer Deutsche und italienische Literatur 1945-1970: Felder, Polysysteme, Transfer, edited by I. Fantappiè and M. Sisto, Istituto Italiano di Studi Germanici, Roma, 2013, http://www.germanistica.net/2014/04/30/cinque-tesi-sulla-traduzione-in-fortini-selection-e-marquage-in-il-ladro-di-ciliegie/

Fortini Franco, Disobbedienze II. Gli anni della sconfitta. Scritti sul Manifesto 1985-1994, Manifestolibri, Roma, 1998.

Fortini Franco, I confini della poesia, Castelvecchi, Roma, 2015.

Fortini Franco, L'Ospite ingrato: primo e secondo, Quodlibet, Macerata, 2003.

Fortini Franco, Letters, Fondo Franco Fortini, Uniwersytet w Sienie.

Fortini Franco, Lezioni sulla traduzione, edited by M. Tirinato, Quodlibet, Macerata, 2011.

Fortini Franco, Libertà vo cercando [annex to 'Manifesto'], Edizioni del Manifesto, Roma, 1982.

Fortini Franco, Per una piccola Enciclopedia della Letteratura italiano: anno 2029, in Autodizionario degli scrittori italiani, edited by F. Piemontese, Leonardo, Milano, 1989, p. 157.

Fortini Franco, Poems (transl. by M. Hamburger) Arc Publications, Todmorden 1978.

Fortini Franco, Saggi ed epigrammi, edited by L. Lenzini, Mondadori, Milano, 2003. Fortini Franco, Sere in Valdossola, Marsilio, Venezia, 1985.

Fortini Franco, Summer is not all. Selected poems (transl. by P. Lawton), Carcanet, Manchester 1992.

Fortini Franco, Ten poems (translated by E. Passannanti), Mask press, Kindle.

Fortini Franco, Tłumacząc Brechta, 'Dekada Literacka', 1995, no. 9, p. 9.

Fortini Franco, Tutte le poesie, edited by L. Lenzini, Mondadori, Milano, 2014.

Fortini Franco, Un dialogo ininterrotto: interviste 1952-1994, edited by D. Abati, Bollati Boringhieri, Torino, 2003.

Fortini Franco, Un'occasione mancata. Il fiore del verso russo, 'Avanti!', 3.12.1949, p. 3.

Fortini Franco, Varsavia 1939, Varsavia 1944, 'L'Avvenire dei lavoratori' 31.08.1944, p. 3.

Fortini Franco, Varsavia 1943. Passato e non passato, 'Il circolo', 1992, p. 4.

Fortini Franco, Warszawa [with no indication of the author, translation of. S. Baliński], 'Robotnik polski w Wielkiej Brytanii', 15/11/1944, no. 22, p. 1 [reprint in S. Baliński Wiersze zebrane 1937-1947, Nakładem Stowarzyszenia Pisarzy Polskich, Londyn, 1948, pp. 299-300].

Fortini Franco, Warszawa 1939 [translated by Anna Kamieńska], in: Polska w poezji narodów świata: antologia wierszy o Polsce, edited by J. Śpiewak, PIW, Warszawa, 1959, p. 371.

Fortini Franco, Warszawa 1944, in: Warsaw Concerto. Powstanie warszawskie w poezji, edited by K. Kunert, Muzeum Powstania Warszawskiego, Warszawa, 2004, p. 581. 
Ghini Giuseppe, Tradurre il ritmo del poeta. Puškin nelle "versioni ritmiche" di Renato Poggioli, 'Studi Slavistici', II (005), pp. 81-9.

Giovannetti Paolo, G. Lavezzi, La metrica italiana contemporanea, Carocci, Roma, 2010.

Jaworska Krystyna, Varsavia 1944: Franco Fortini e Stanisław Baliński, in Italia Polonia Europa, scritti in memoria di Andrzej Litwornia, edited by A. Ceccherelli et alii, Polska Akademia Nauk w Rzymie, Rzym, 2007, pp. 182-195.

Lenzini Luca, Introduzione, in: Franco Fortini, Tutte le poesie, edited by L. Lenzini, Mondadori, Milano, 2014, pp. V-XLIV.

Manfredi Anna, Fortini traduttore di Eluard, Pacini Fazzi, Lucca, 1992.

Mengaldo Pier Vincenzo, Allusione e intertestualità: qualche esempio, 'Strumenti critici', 2015, no. 3, pp. 381-404.

Mengaldo Pier Vincenzo, La tradizione del Novecento, Quarta serie, Bollati Boringhieri, Torino, 2000.

Miszalska Jadwiga, Letteratura e impegno: la critica di Franco Fortini e la sua concezione della letteratura, Universitas, Kraków, 1993.

Organte Laura, Poesia e traduzione a Firenze (1930-1950), Libreraiauniversitaria.it, Padova, 2018.

Per voci interposte. Fortini e la traduzione, edited by F. Diaco, E. Nencini, Quodlibet, Macerata, L'ospite ingrato, 2019.

Peterson Thomas E., The ethical Muse of Franco Fortini, Un. Press of Florida, Gainesville, 1997.

Poggioli Renato, Puskin lirico, 'Letteratura. Rivista trimestrale di letteratura contemporanea', 1 (1937), no. 3, p. 128-129.

Pushkin Alexander, La plebe, traduzione metrica dal russo, translated by R. Poggioli, 'Campo di Marte', II, no. 9, 1-15.05.1939, p. 3.

Raboni Giovanni, Temi resistenziali e "stile da traduzione" in Foglio di via, 'Paragone', 1980, issues no. 360-362, pp. 163-167.

Sabbatino Pasquale, Fortini e la figura di Adamo. Il senso tragico della storia e della poesia, 'Otto/Novecento', 14 (1990), issues no. 3-4, May-August, pp. 59-77.

Savioli Silvia, La curiosa fortuna del Fiore ovvero note sulla recezione critica, in: Cesare Pavese, Renato Poggioli, A meeting of minds: carteggio 1947-1950, edited by S. Savioli, Edizioni dell'Orso, Alessandria, 2010.

Tomassucci Giovanna, Una traduzione dimenticata: 'Poesia agli adulti' di Adam Ważyk, in: 'L'Ospite ingrato', 2019 [monographic issue dedicated to Franco Fortini], pp. 45-65. 


\title{
Od Warszawy do Warszawy. Parę uwag o dwóch 'wyimaginowanych przekładach' z polskiego (1944) Franco Fortiniego
}

\section{Streszczenie}

Podczas politycznego wygnania w Szwajcarii, włoski poeta Franco Fortini opublikował anonimowo dwa wiersze (Warszawa 1943, Warszawa 1944), podając je za tłumaczenia tekstów napisanych w okupowanej Polsce. W ten sposób poeta po raz pierwszy eksperymentował na wyimaginowanych przekładach $\mathrm{z}$ nieistniejących oryginałów. Odwoływanie się do tradycji „literackich oszustw”, praktykowanej wcześniej przez Macphersona i Leopardiego, pomagało mu w poszukiwaniu form i „słów” dla nowej wojennej poezji. Artykuł zestawia „polskie” wiersze Fortiniego z jego późniejszymi wystąpieniami teoretycznymi, w których poeta analizuje relację wyimaginowanych przekładów do „imitacji lub parodii” w kontekście dominującego w środowisku literackim postrzegania danej literatury. Zwraca również szczególną uwagę na silną intertekstualność obu wierszy oraz na ukrytą w nich krytykę włoskiej praktyki translatorskiej.

Słowa kluczowe: Włoska poezja XX wieku; Wyimaginowane przekłady; Studia o przekładzie.

\section{From Warsaw to Warsaw. Some remarks on the two 'imaginary translations' from Polish (1944) by Franco Fortini}

\author{
Summary
}

The article analyses Franco Fortini's two poems written in 1944 during his exile in Switzerland: Warsaw 1939 and Warsaw 1944 (the latter's former title was Warsaw 1943). The poet defined them Imaginary Translations, because he conceived them as translated from an inexistent original, written in occupied Poland. In this way, the Italian poet experimented for the first time with imaginary translations. Following Macpherson and Leopardi's tradition of "Literary Hoaxes", he sought new forms and "new words" for Poetry on WW II. The article compares the Fortini's 
"Polish" poems with later comments on Imaginary translations (they are akin to "Imitation or Parody", are created "taking delight in prank and experiment" and derive from a certain dominant conception of a foreign literature), paying particular attention to their strong intertextuality and their allusions to the practice of translating poetry in Italy.

Keywords: $2 \mathrm{O}^{\text {th }}$-Century Italian Poetry, Imaginary translations, Translation Studies

Giovanna Tomassucci, profesor Polskiej Literatury i Języka polskiego na Wydziale Filologia, Linguistica e Letteratura Uniwersytetu w Pizie (Włochy). Jej zainteresowania badawcze obejmowały polską literaturę epoki renesansu, baroku, romantyzmu i XX-XXI wieku. Jej działalność badawczo-naukowa ostatniego okresu dotyczy polsko-włoskich literackich relacji i kulturowych rozdroży między tradycją żydowską a polską literaturą XX wieku.

Giovanna Tomassucci, Associate Professor of Polish Literature and Language in the Department of Filologia, Linguistica e Letteratura at the University of Pisa (Italy). Her research activity was devoted to Polish Renaissance, Baroque, Romanticism and XX-XXI centuries literature. Her last researches comprise studies on Polish-Italian cultural relations and crossroads between Jewish tradition and Polish $20^{\text {th }}$-century literature. 